\title{
Ethnobotany of Lontar (Borassus flabellifer L.) in Tuamese Village, East Nusa Tenggara
}

\section{(Etnobotani Lontar (Borassus flabellifer L.) di Desa Tuamese, Nusa Tenggara Timur)}

\author{
Ite Morina Yostianti Tnunay ${ }^{\star}$, Dicky Frengky Hanas
}

(Diterima September 2021/Disetujui Oktober 2021)

\begin{abstract}
Lontar is a plant that distributed in tropical areas and has beneficial values for the people in Tuamese Village, Biboki Anleu District, North Central Timor Regency. However, the information about the ethnobotany of lontar is not documented. This research aimed to determine the utilization of lontar in Tuamese Village. Data were collected using semi-structured interview techniques and field observation. The ethnobotany data were analyzed to calculate cultural significance index value. The results showed that the people in Tuamese Village who generally work as lontar farmers use stem, leaves, flowers, and fruit as building and fence materials, handicraft materials, food and drink ingredients, and firewood. Product from sap flower, namely liquid sugar, slab sugar, and traditional fermented drink (sopi) are the leading trade commodity. The utilization of lontar in Tuamese Village is grouped into seven forms of utilization with index of cultural significance 151 and classified very high. The classification means that lontar greatly affects people's lives in Tuamese Village and its use has become cultured. People's dependence on lontar is very high so the conservation effort needs to make the existence of lontar is maintained.
\end{abstract}

Keywords: index cultural significance, lontar, Tuamese

\section{ABSTRAK}

Lontar merupakan tumbuhan yang tersebar di daerah tropis dan memiliki nilai manfaat bagi masyarakat di Desa Tuamese, Kecamatan Biboki Anleu, Kabupaten Timor Tengah Utara. Namun, informasi tentang etnobotani lontar belum tersedia. Penelitian ini bertujuan untuk mengetahui pemanfaatan lontar di Desa Tuamese. Pengumpulan data dilakukan dengan menggunakan teknik wawancara semi terstruktur dan observasi lapangan. Data etnobotani selanjutnya dianalisis untuk menghitung Indeks Kepentingan Budaya. Hasil penelitian menunjukkan bahwa masyarakat Desa Tuamese yang umumnya berprofesi sebagai petani lontar menggunakan batang, daun, bunga, dan buah sebagai bahan bangunan dan pagar, bahan kerajinan, bahan makanan dan minuman, serta kayu bakar. Produk nira dari bunga lontar, yaitu gula cair, gula lempeng, dan minuman fermentasi tradisional (sopi), merupakan komoditas unggulan yang diperdagangkan. Pemanfaatan lontar di Desa Tuamese dikelompokkan menjadi tujuh bentuk pemanfaatan dengan Indeks Kepentingan Budaya sebesar 151 dan tergolong sangat tinggi. Klasifikasi tersebut berarti lontar sangat mempengaruhi kehidupan masyarakat di Desa Tuamese dan penggunaannya sudah membudaya. Ketergantungan masyarakat terhadap lontar sangat tinggi sehingga perlu upaya konservasi agar keberadaan lontar tetap terjaga.

Kata kunci: indeks kepentingan budaya, lontar, Tuamese

\section{INTRODUCTION}

Lontar (Borassus flabellifer L.) is a plant from the Arecaceae group that lives spread in tropical climates, including Indonesia. Lontar has a high value because almost all parts can be used, from roots to fruit. Lontar is useful as food, building material, household furniture, and art or cultural materials (Fajeriadi et al. 2019). People in Mount Bromo, East Java, use lontar leaves as containers for traditional events, crafts, and media

Study Programme of Biology, Faculty of Agriculture, Universitas Timor, Jl. Km 9, Sasi, Kefamenanu, Nusa Tenggara Timur, 85613

${ }^{*}$ Correspondence author:

Email: itetnunay@gmail.com for painting (Thibab et al. 2019). In Sabu Island, East Nusa Tenggara uses lontar as a source of food, watercarrying equipment, fishing gear, drums, and traditional ceremonies (Age et al. 2019). Lontar fruit contains carbohydrates, protein, antioxidants, and water used as alternative food (Vengaiah et al. 2015; Rodiah et al. 2019). Lontar has high adaptability to dry environments, so it is commonly found in dry areas, especially in East Java and eastern Central Java, Madura, Bali, West Nusa Tenggara, East Nusa Tenggara, and Sulawesi. Lontar, also known as siwalan, was appointed as flora identity of South Sulawesi (Nasri et al. 2019).

The largest population of lontar is found in East Nusa Tenggara and South Sulawesi. In East Nusa Tenggara, lontar trees can be found on the north to the 
south coast of Flores and Timor islands, east and south coasts of Sumba island, and on small islands. The largest concentrations of lontar are found in Kupang Regency (West Timor Island), Rote Island, and Sabu Island), East Sumba Regency (Rindi Umalulu District and Pahungalodu District), South Central Timor Regency, Belu (South and North), and East Flores. Lontar tree in East Nusa Tenggara has various local names such as akadirun (Tetun), balelahe (Alor), kapuwe duwe (Sabu), kodi (Sumba), and tua (Timor) (Tambunan 2010).

North Central Timor is a regency in East Nusa Tenggara where lontar species have also been found but not documented. Lontar species in North Central Timor are found in Tuamese Village, Biboki Anleu District. However, ethnobotany studies of lontar in Tuamese Village have not been carried out and documented, even though this information is essential for the uses and development of lontar plants in the future. Therefore, it is necessary to conduct an ethnobotanical study of the lontar found in Tuamese Village, Biboki Anleu District, North Central Timor Regency. This research aimed to determine the utilization of lontar in Tuamese Village.

\section{MATERIAL AND METHODS}

\section{Research Subject}

This research was conducted from October to December 2020 in Tuamese Village, Biboki Anleu District, TTU Regency. The tools and materials used are camera and lontar specimens.

\section{Researh Method}

The method used is interviews and field observations. Interviews were conducted using semistructured and in-depth interview methods (Tardio \& de Santayana 2008; Singh \& Singh 2009). Respondents were interviewed according to the questions that have been made. The respondents used were 10 people who were determined by ethnic group, age: over 20 years old, gender: male and female, and worked as lontar farmers. The 10 respondents consist of 5 person from Sabunnese ( 3 man and 2 women) and 5 person from Rotenesse ( 3 man and 2 women). Timoresse was not chosen because lontar farmers in Tuamese only comes from Sabunesse and Rotenesse. We also developed questions adapted to the respondent's answers. Field observations were carried out by observing using lontar by the people in Tuamese Village, Biboki Anleu District, TTU Regency. The results of the observations and the parts of the lontar used are then documented.

\section{Data Analysis}

The ethnobotanical data using to calculated the Index of Cultural Significance (ICS). ICS is the result of quantitative ethnobotanical analysis that shows the importance of each plant species based on people needs which includes 3 aspects, namely: quality of "use" (q), intensity of "use" (i) and exclusivity of "use" (e) (Turner 1988; Basir et al. 2015). The Cultural Interest Index is calculated by the formula:

$$
\begin{aligned}
\mathrm{ICS}= & \sum_{\mathrm{i}=1}^{\mathrm{n}}\left(q_{1} x i_{1} x e_{1}\right) n_{1}+\left(q_{2} x i_{2} x e_{2}\right) n_{2}+\cdots+ \\
& \left(q_{n} x i_{n} x e_{n}\right) n_{n}
\end{aligned}
$$

ICS : Index of Cultural Significance: the number of uses of a plant species from 1 to which indicates the umpteenth use

q : Quality of "use", calculated by giving a score or quality value of a type. Scoring: $5=$ primary food; $4=$ secondary food and primary materials; $3=$ other use food, secondary materials, and medicine; $2=$ traditional rituals, mitology, recreation, and other uses; $1=$ mere recognition

i : Intensity of "use", describe the impact of a plat day-to-day lives of people within the culuture. Scoring: $5=$ very high intensity; $4=$ moderately high use intensity, $3=$ medium use intensity; $2=$ low use intensity; $1=$ minimal use intensity.

e : Exclusivity of "use", the value consider the extent to which a particular type pf plant. Scoring: 2= describe the most preferred choice; $1=$ describe there is more than one/some of the preferred uses; 0,5= secondary resources.

\section{RESULTS AND DISCUSSIONS}

\section{General Description of Research Location}

The name of Tuamese Village means "one tua or one lontar". The name Tuamese stems from the discovery of a lontar tree that is taller than other lontar trees. Tuamese Village is located in Biboki Anleu District, North Central Timor Regency, with $14 \mathrm{~km}^{2}$ (BPS TTU 2018). The Ombai Strait borders the Tuamese village to the north, Kotafoun Village to the south, Nonatbatan Village to the east, and Ponu Village. The total population in 2019 was 1409 people, with 557 males and 852 females, most of whom only graduated from elementary school.

Most people living in Tuamese Village are from the Rotenesse, Sabunesse, and Dawanesse/Timorese, while the indigenous tribes, namely Dawan Belunesse (Harnenotuan), are now fewer in number because they have migrated to other areas. Over time, people no longer mention the origin of the existing tribes but later renamed their tribe Tirosa, an abbreviation of Timor, Rote, and Sabu.

The majority of the population in Tuames Village work as lontar farmers. The people also grows several agricultural crops such as lowland rice, field rice, papaya, chili, green beans, peanuts, and rice beans which are used to meet basic needs and are sold. The plantation crops cultivated are coconut, cashew, jackfruit, areca nut, tangerine, mango, castor betel, and betel. People in Tuamese Village also raise livestock 
such as cows, pigs, and goats with a loose system so that peoples generally use lontar leaf stalks to make fences so that the yard is not entered by livestock.

\section{Utilization of Lontar}

In general, lontar are used by the people in Tuamese Village as building and fence materials, handicraft materials, food and drink ingredients, and firewood (Table 1). The parts used are stems, leaves, flowers, and fruit. Initially, the Dawan Belu people only used stems and leaves for building materials and crafts and fruit for consumers. Utilization of the flower part began when the Rote and Sabu Tribes came and settled in this village. The lontar flower is then tapped for its sap and then used as raw material for making liquid sugar, slab sugar, and traditional drinks (tuak and sopi). The product from nira is then sold by the people and becomes the primary livelihood source for most people in Tuamese Village.

Men and women in Tuamese Village play different roles in using lontar. The use of lontar as a building material usually was done by men, while women did the use of food and crafts. For example, in the utilization of lontar sap, men are tasked with tapping lontar sap and then, together with women, process it.

The lontar stems used as building materials come from old trees. The lontar stems can be directly used as house poles (Figure 1a). However, it must first be split into several parts according to the specified size (Figure 1b). The middle part of the rod for roofing wood is removed first because it is easily weathered. Flower pots made from lontar stems are made by dividing the lontar stems into smaller pieces $( \pm 40 \mathrm{~cm})$ and then removing the middle and filling them with soil (Figure 1c).

Lontar petiole used for fences usually use dried leaves. The people collects dry leaves and then discards the leaves. The leaf petiole are then arranged alternately on the wooden wall (Figure 1d). The petiole used for the seating are used by nailing them to the prepared wood (Figure 1e). The petiole used to make chicken baskets are young because they are easier to cut and do not break easily. The petiole is divided into several parts and then trimmed to make it neater and slightly thinner. The petiole are then weaved according to their shape (Figure 1f).

The lontar leaves use as building materials, household materials, and craft materials. Lontar leaves for building materials (roof) use old leaves. The old leaves are tied with the help of a rope to the roof wood that has been made (Figure 1g). Lontar leaves for household and craft materials use young leaves for easy weaving. The leaves are taken from the tree, and then the sticks are removed and trimmed to a specific size. Leaves can be woven into household materials: fans, places to store food and food ingredients (Figure 1h), winnowing tool (Figure 1i), small basket (Figure 1j), slab sugar mold (Figure 1k), betel nut container (Figure 1I), material container (Figure $1 \mathrm{~m}$ ), and a traditional hat (Figure $1 \mathrm{n}$ ). The people of the Rote Tribe only use traditional hats as a complement to traditional clothing.

The people in Tuamese Village uses male flowers and female flowers as a producer of sap. The sap is accommodated in a jerry can on a tree and then lowered down. The liquid can be drunk directly (tuak) or processed into liquid sugar (Figure 10), slab sugar (Figure 1p). Nira can also be used as an ingredient in fermented drinks (sopi) (Figure 1q). Female flowers are allowed to continue to develop to fruit. On the inside of the lontar fruit, there is edible flesh (endosperm).

Processed products of lontar sap are sopi, liquid sugar, and slab sugar. Sopi is a fermented drink made using lontar sap. Making sopi takes approximately two days. Sopi is then packaged in $600 \mathrm{ml}$ bottles and sold at prices ranging from IDR 30,000 to IDR 40,000 per bottle. Making liquid sugar begins with boiling the sap until it thickens and forms liquid sugar. Usually, from 10 liters of sap, only 1.5-2 liters of sugar are produced. Furthermore, the liquid sugar is then put into a bottle, or jerry can then be used as an ingredient for drinks and cooking. One jerry can of sugar liquid is usually sold at Rp. 150.000,-- Making liquid sugar takes between 4-5 hours.

The production of slab sugar begins with a filter for the lontar sap to be cooked (Figure 2a). The sap is then heated briefly before use to prevent acidity (Figure $2 b$ ). After being heated briefly, the sap is then cooked in four pots in stages (Figure 2c). The furnace is made of earth, covered in all parts, and only given four holes at the top to put pots and one hole at the end for inserting firewood. Such a furnace system causes furnace four to receive more fire than furnaces three, two, and one. The sap that has been heated for a while will be put in pot one and cooked for a while, then transferred to pot two. After the second pot, the sap is transferred to the third pot and then to the fourth pot. The sap in pot four will continue to be cooked until it thickens to form very thick liquid sugar (Figure 2d). The liquid sugar is then put in a container of coconut and stirred until it cools a

Table 1 Utilization of lontar in Tuamese Village

\begin{tabular}{ll}
\hline Plant Organ & \multicolumn{1}{c}{ Utilization } \\
\hline Stem & Building material: house pole, roof wood, planting place \\
Leaves & Petiole: fence, seat (para-para), firewood, chicken basket, cordage \\
& Blade: Building material: roof; handicraft materials: fan (ganggere, pe'se, kakehi), food container, winnowing \\
& tool (kakoko, tupa, barafai), small basket, slab sugar mold, betel nut container, material container, traditional \\
& hat (Ti'i Langga) \\
Flower & Sap (tuak), products from sap: traditional fermented drink (sopi), liquid sugar, slab sugar \\
Fruit & Food ingredients: endosperm part (saboak) \\
\hline
\end{tabular}




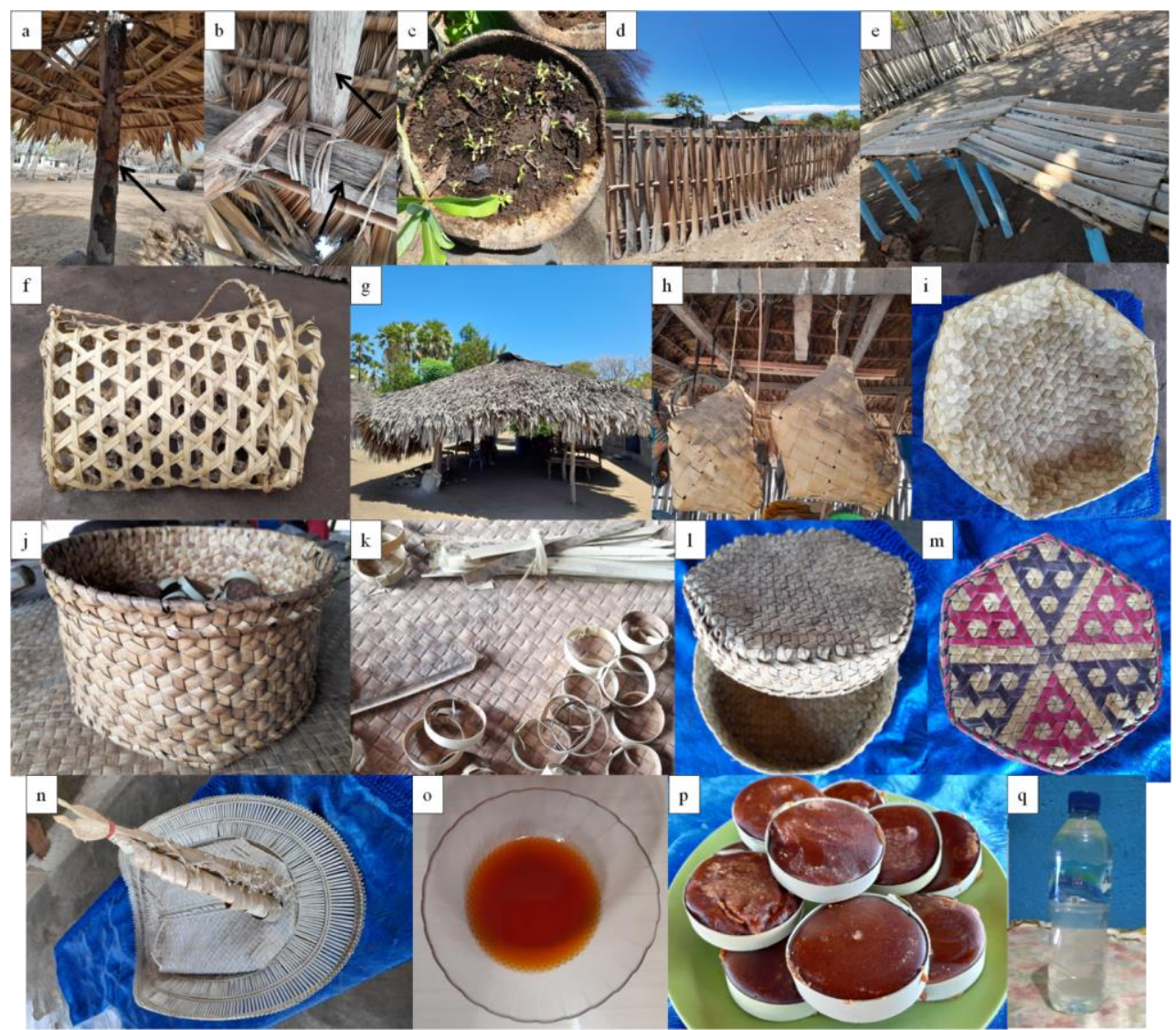

Figure 1 Utilization variety of lontar in Tuamese Village. a. house pole; b. roof wood; c. planting place; $d$. fence; e. seat; $f$. chicken basket; g. roof; h. food container; i. winnowing tool; j. small basket; k. slab sugar mold; I. betel nut container; m. material container; n. traditional hat; o. liquid sugar; p. slab sugar; q. traditional fermented drink (sopi)
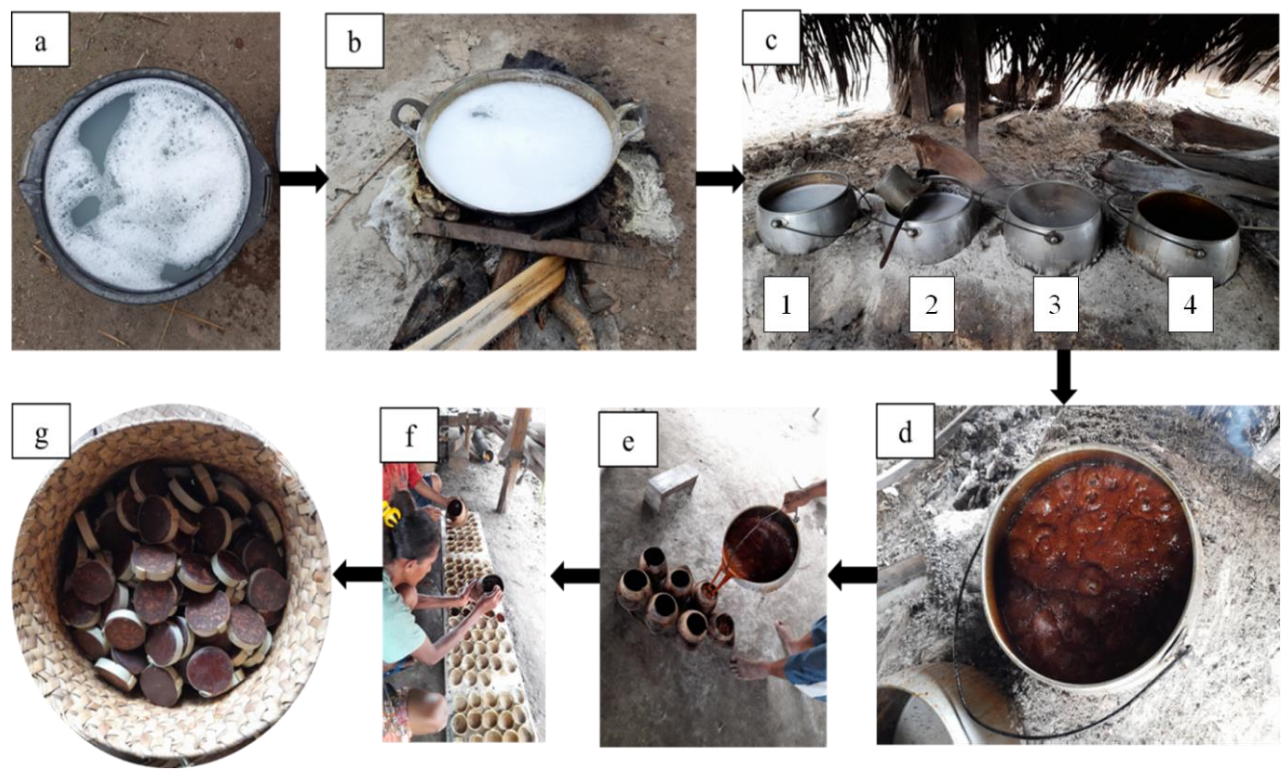

Figure 2 Making sugar plates in Tuamese Village. a. sap that has been filtered; b. the sap is heated briefly; c. sap cooked on the stove; $d$. liquid sugar; e. liquid sugar is transferred to a container; f. liquid sugar is poured into the mold; g. slab sugar ready to use

bit (Figure 2e). Slab sugar is molded by pouring liquid sugar into a round mold made of lontar leaves (Figure 2f). The dried powdered sugar was then removed (Figure 2g). The plated sugar that has been produced is then sold at Rp. 20,000,- up to Rp. 25.000-/kg.
People in Tuamese Village use lontar as buildings and fences, handicraft materials, food and drink ingredients, and firewood. Some alternative uses of lontar are leaves for water containers (haik), leaf bones for broomsticks, roots for drums or tambur (Age et al. 
2019), lontar sap as additional feed for pigs (Jehamat et al. 2017), and raw material for bioethanol (Haisya et al. 2011). The part that provides economic benefits for the people is lontar sap because the processed product can be sold. Lontar sap quality varies depending on genetic characteristics and tree metabolites, environmental factors, collection time, microbial load, personal hygiene, and sanitation equipment. Microorganisms may be a significant factor in the quality of lontar sap because they use sugar as a substrate to produce organic acids and ethanol. This organic acid causes an inversion reaction, while ethanol has an unpleasant taste from lontar sap. The 2,3,4-trihydroxy-5methylacetophenone compound isolated from lontar sap acts as an antibacterial against Escherichia coli, Staphylococcus aureus, Mycobacterium smegmatis, and Staphylococcus simulans (Kurniawan et al. 2018).

The processing of lontar sap in Tuamese Village is done traditionally by using the heating technique. During heating in an open pan using high temperatures and for a long time will involve caramelization and Maillard reactions. This reaction requires reducing sugars and precursor amino acids (Saputro et al. 2019). The high-temperature treatment causes the phenolic and antioxidant compounds in the sap to decrease and causes the resulting sugar to taste a bit bitter. The use of an evaporator and, in a shorter time, reduces the inversion of sucrose (Kurniawan et al. 2018).

\section{Index Cultural Significant}

The utilization of lontar in Tuamese Village is grouped into seven forms of utilization with a index of the cultural significant of 151 (Table 2). The seven form utilization are primary food: form fruit (saboak); secondary food: beverage or drink ingredients (sap, product from sap traditional fermented drink (sopi); other food related uses: sweetening and flavoring (liquid sugar and slab sugar); primary materials: wood for implements, containers, and construction (hose pole, roof wood, fence, seat); secondary materials: binding and water proofing (cordage, roof), secondary materials: miscellaneous useful materials (handicraft: fan (ganggere, pe'se, kakehi), food container, winnowing tool (kakoko, tupa, barafai), small basket, slab sugar mold, betel nut container, material container, traditional hat (Ti'i Langga)); and miscellaneous: naming of village.

According to the cultural perception of the Tuamese village community, the lontar species have 7 categories of uses. The highest score is Secondary food as beverage, with an ICS value of 40; followed by Secondary materials as miscellaneous useful materials, with an ICS value of 30 ; then form fruit as primary food, wood for implements, containers, and construction as primary material, and miscellaneous for naming of village, each with an ICS value of 20 ; and finally the relatively small ICS value for sweetening and flavoring uses which are categorized as Other food related uses with a value of 12 , and binding and water proofing uses categorized as secondary materials, with a value of 9 .

According to (Turner 1988), ICS scores are grouped into several categories, namely very high significance ( $\geq 100)$, high significance (50-99), moderate signifi-

Table 2 Index cultural significant of lontar in Tuamese Village

\begin{tabular}{|c|c|c|c|c|}
\hline Utilization form & $\mathrm{q}$ & $\mathrm{i}$ & $\mathrm{e}$ & Result of calculation \\
\hline Primary food: form fruit & 5 & 4 & 1 & 20 \\
\hline Secondary food: beverage & 4 & 5 & 2 & 40 \\
\hline Other food related uses: sweetening and flavoring & 3 & 4 & 1 & 12 \\
\hline Primary materials: wood for implements, containers, and construction & 4 & 5 & 1 & 20 \\
\hline Secondary materials: binding and water proofing & 3 & 3 & 1 & 9 \\
\hline Secondary materials: miscellaneous useful materials & 3 & 5 & 2 & 30 \\
\hline Miscellaneous: naming of village & 2 & 5 & 2 & 20 \\
\hline ICS & & & & 151 \\
\hline
\end{tabular}

Based on the quality of use (q):

a. Fruit is categorized as primary food, with a value of 5 ;

b. Beverage as a secondary food, but wood for implements, containers, and construction as a primary material, each with a value of 4 (secondary food and primary materials);

c. Sweetening and flavoring are categorized as Other food related uses, then binding and water proofing, and miscellaneous useful materials, are categorized as Secondary materials, with a value of 3 each (other use food, secondary materials, and medicine);

d. Lontar also means a village, and therefore it is categorized into miscellaneous, with a value of 1 (mere recognition).

Based on the intensity of use (i):

a. Beverage as secondary food; Wood for implements, containers, and construction primary materials; Miscellaneous useful materials as secondary materials and naming of village as Miscellaneous, each with a value of 5 (very high intensity)

b. Fruit as Primary food; sweetening and flavoring as other food related uses with a value of 4 (moderately high use intensity)

c. Binding and water proofing as secondary materials with a value of 3 (medium use intensity)

Based on the exclusivity of use (e):

a. Beverage as secondary food; miscellaneous useful materials and naming of village as miscellaneous as secondary materials with a value of 2 (the most preferred choice).

b. Fruit as primary food; Sweetening and flavoring as other food related uses; Wood for implements, containers, and construction as primary materials; Binding and water proofing as secondary materials with value of 1 (there is more than one/some of the preferred uses) 
cance (20-49), low significance (5-19), very low significance (1-4), and negligible significance (0). The results of the ICS analysis show that the of utilization of lontar in Tuamese Village is classified as very high. The very high ICS value shows that lontar greatly affects people's lives in Tuamese Village and its use has become cultured. It can be seen from the use of the local lontar name "tuamese" as the name of the village and the utilization form of lontar. The use of lontar sap and its processed product (sopi), is included in secondary food with a very high intensity of use and is used throughout the year by the people in Tuamese village. Besides for sold, people use sopi as a traditional drink which is usually served at weddings or funerals. Other processed nira products, namely liquid sugar and slab sugar, are used as sweeteners in sugar substitutes. Lontar fruit is a primary food but the intensity of its use is moderate because it depends on the fruiting season.

Another utilization form of lontar is as the primary material because the stem is used as a hose pole, roof wood, fence, and seat. The use intensity of lontar as the main material is high because people generally take it directly from the trees around the house and use it as needed. The use of lontar as secondary materials can be seen in the use of leaves for cordage and leaf blades for roofs with moderate utilization intensity and as an alternative roofing material and rope. The community also uses leaves as the main raw material for making handicrafts, such as fan (ganggere, pe'se, kakehi), food container, winnowing tool (kakoko, tupa, barafai), small basket, sugar mold slab, betel nut containers, container materials, traditional hat (Ti'i Langga). The intensity of the use of lontar as the main raw material for handicrafts is very high because it produces household utensils that are used for daily needs.

Lontar is a long-lived plant so that it can take years to grow to the production phase. The productive age of lontar trees for tapping sap is between 15-30 years (Kurniawan et al. 2018). This very long growing time and productive phase require conservation efforts to be carried out as early as possible. However, the people also realizes that the number of lontar in Tuamese Village, which is still productive, decreases from time to time because many are old and dead. In addition, many seeds do not germinate properly due to unfavorable environmental conditions, and the newly sprouted lontar can be damaged or die from being stepped on by the released pets. Therefore, efforts to maintain habitat areas and planting and maintenance are needed so that lontar, which is the source of livelihood for most people, is held.

\section{CONCLUSION}

Tuamese village means "one tua or one lontar". People in Tuamese Village use stem, leaves, flower, and fruit as building and fence materials, handicraft materials, food and drink ingredients, and firewood.
The product of lontar flower sap namely liquid sugar, slab sugar, and traditional fermented drink (sopi) are used as the main commodities for trade. The utilization of lontar in Tuamese Village is grouped into seven forms of utilization with index cultural significance is 151 and it is classified as very high, so the conservation effort needs to make the existence of lontar is maintained.

\section{ACKNOWLEDGEMENT}

We would like to thank the Research and Community Service Institute of Universitas Timor for allowing this research to be carried out. We also say thank you to the Tuamese Village government and respondents who assisted during the research.

\section{REFERENCES}

Age DL, Hendrik Ach and Rupidara AND. 2019. Ethnobotany study of lontar tree (Borassus flabellifer L.) at Raijua Island. Proceeding of International Seminar on Chemical Engineering Soehadi Reksowardojo (STKSR). https://doi.org/ 10.1088/1757-899X/823/1/012048

[BPS TTU] Badan Pusat Statistik Kabupaten Timor Tengah Utara. 2018. Kecamatan Biboki Anleu dalam Angka. Kefamenanu (ID): BPS Kabupaten Timor Tengah Utara.

Basir AA, Lahjie AM, Simarangkir BDAS, Matius P. 2015. Mengukur kepentingan budaya dari sumber daya hutan melalui kajian etnobotani kuantitatif. Jurnal Teknologi Pertanian. 10(1): 8-17.

Fajeriadi H, Dharmono, Anwar MR. 2019. Kerapatan Iontar (Borassus flabellifer L.) di Hutan Pantai Desa Tabanio, Kalimantan Selatan. Enviro Scienteae. 15(2): 190-194. https://doi.org/10.20527/es.v15i2.6 949

Haisya NBS, Utama BD, Edy RC, Aprilia HM. 2011. The potential of developing siwalan lontar sugar (Borassus flabellifer L.) as One of the Bioethanol Sources to Overcome Energy Crisis Problem in Indonesia. Proceeding of 2nd International Conference on Environmental Engineering and Applications IPCBEE. 17: 89-93.

Jehamat A, Moenthe UG, Katipana N. 2017. Pemanfaatan nira lontar sebagai bahan pakan sumber energi tambahan bagi ternak babi dan perbandingannya untuk memproduksi gula. Partner. 1: 87-93.

Kurniawan T, Jayanudin, Kustiningsih I, Firdaus MA. 2018. Palm sap sources, characteristics, and utilization in Indonesia. Journal of Food and Nutrition Research. 6(9): 590-596. https://doi.org/1 0.12691/jfnr-6-9-8 
Nasri, Suryaningsih, Kurniawan E. 2019. Ekologi pemanfaatan, dan sosial budaya lontar (Borassus flabellifer L.) sebagai Flora Identitas Sulawesi Selatan. Info Teknis EBONI. 14(1): 35-46.

Rodiah MH, Jamilah B, Kharidah SM, Russly AR. 2019. Physico-chemical and antioxidant properties of mesocarp and exocarp from Borassus flabellifer. International. Food Research Journal. 26(5): 1469-1476.

Saputro AD, de Walle DV, Dewettinck K. 2019. Palm sap sugar: a review. Sugar Tech. 21: 862-867. https://doi.org/10.1007/s12355-019-00743-8

Singh A, Singh PK. 2009. An ethnobotanical study of medicinal plants in Chandauli District of Uttar Pradesh, India. Journal of Ethnopharmacology. 121(2): 324-329. https://doi.org/10.1016/j.jep.2008. 10.018

Tambunan P 2010 Potensi dan kebijakan pengembangan lontar untuk menambah pendapatan penduduk. Jurnal Analisis Kebijakan Kehutanan. 7(1): 27-45. https://doi.org/10.20886/ja kk.2010.7.1.27-45
Tardio J, de Santayana MP. 2008. Cultural Importance Indices: A comparative analysis based on the useful wild plants of Southern Cantabria (Northern Spain). Economic Botany. 62(1): 24-39. https://doi.org/10.1 007/s12231-007-9004-5

Thibab N, Hayati A, Zayadi H. 2019. Studi etnobotani dan distribusi tanaman siwalan di Desa Gapura Timur Kecamatan Gapura Kabupaten Sumenep Suku Madura. e-Jurnal Ilmiah Biosaintropis. 4: $15-20$.

Turner NJ. 1988. The Importance of a Rose": Evaluating the cultural significance of plants in Thompson and Lillooet Interior Salish. American Anthropologist. 90(2): 272-290. https://doi.org/10.1 525/aa.1988.90.2.02a00020

Vengaiah PC, Kumara VB, Murthy GN, Prasad KR. 2015. Physico-chemical properties of palmyrah fruit pulp (Borassus flabellifer L). Nutrition and Food Sciences. 5(5): 1-4. https://doi.org/10.4172/2155 9 600.1000391 